\title{
TANGGAPAN DUNIA INDUSTRI TERHADAP SOFT SKILLS DAN HARD SKILLS DALAM PELAKSANAAN PRAKTIK KERJA INDUSTRI SISWA DPIB SMKN 2 GARUT
}

\author{
Winda Darmayanti ${ }^{1}$, Nandan Supriatna $^{2}$, dan Siti Nurasiyah ${ }^{3}$ \\ 1,2,3 Pendidikan Teknik Bangunan, FPTK, UPI \\ Email: wdarmayanti.wd@gmail.com
}

\begin{abstract}
ABSTRAK
Berkualitas atau tidaknya mutu pendidikan SMK yang ada di Indonesia sangat dipengaruhi oleh sistem pendidikan yang diterapkan oleh pemerintahan Indonesia saat ini. Pendidikan Sistem Ganda merupakan sistem pendidikan yang menerapkan teknik pendidikan di sekolah dan di dunia industri. Salah satu program dari pendidikan sistem ganda yaitu Praktik Kerja Industri. Dengan melihat penilaian dunia usaha dan dunia industri terhadap kinerja siswa praktikan selama masa praktik kerja industri (prakerin) itu salah satu upaya dalam mengembangkan kualitas sumber daya manusia. Oleh sebab itu penelitian ini bertujuan untuk (1) untuk mengetahui tanggapan dunia industri dalam pelaksanaan praktik kerja industri siswa DPIB SMKN 2 Garut ditinjau dari aspek soft skills dan (2) untuk mengetahui tanggapan dunia industri dalam pelaksanaan praktik kerja industri siswa DPIB SMKN 2 Garut ditinjau dari aspek hard skills. Metode yang digunakan dalam penelitian ini adalah deskriptif kuantitatif dengan teknik pengambilan data melalui kuesioner. Penyebaran kuesioner dilakukan kepada pembimbing atau pendamping siswa prakerin di tiap perusahaan yang telah bekerja sama dengan Program Keahlian Desain Pemodelan dan Informasi Bangunan (DPIB) sebanyak 28 perusahaan, maka teknik pengambilan sampel dalam penelitian ini menggunakan teknik sampling jenuh. Berdasarkan hasil temuan dan pembahasan secara keseluruhan dunia industri menanggapi kemampuan siswa DPIB pada soft skills yaitu baik sedangkan hard skills kurang baik dalam pelaksanaan prakerin, karena ada hal-hal yang belum tercapai dengan maksimal pada tiap indikatornya. Pihak sekolah dapat meningkatkan semua aspek pengembangan pembelajaran siswa SMK, dengan begitu tentu akan meningkatkan kualitas kompetensi siswa sehingga dapat memenuhi kriteria sumber daya manusia yang dibutuhkan oleh dunia industri
\end{abstract}

Kata kunci: Soft Skills, Hard Skills, Praktik Kerja Industri.

\section{ABSTRACT}

The quality or not of the quality of SMKN in Indonesia is greatly influenced by the education system implemented by the current Indonesian government. Dual System Education is an education system that applies education techniques in schools and in the industrial world. One of the dual system education programs is Industrial Work Practices. By looking at the assessment of the business world and the industrial world of student performance during the period of industrial work practice it is one of the efforts in developing the quality of human resources. Therefore, this study aims to (1) find out the responses of the industrial world in the implementation of industrial work practices of DPIB SMKN 2 Garut students in terms of soft skills; and (2) to determine the response of the industrial world in the implementation of industrial work practices of DPIB SMKN 2 Garut students in terms of hard skills. The method used in this research is quantitative descriptive with data collection techniques through questionnaires. Questionnaires were distributed to mentors or mentors of students in the industry in each company that had collaborated with the 28 Model Building Design and Information Skills Program (DPIB), so the sampling technique in this study used saturated sampling technique. Based on the findings and discussion as a whole the industrial world responds to soft skills and hard skills possessed by DPIB students both in the implementation of internship. But there are things that have not been achieved to the maximum on each indicator of soft skills and hard skills. The school can improve all aspects of the development of vocational student learning, thereby increasing the quality of student competence so that it can meet the human resource requirements needed by the industrial world.

Keywords: Soft Skills, Hard Skills, Industrial Work Practices. 


\section{PENDAHULUAN}

Mutu pendidikan di Indonesia saat ini sangatlah berpengaruh terhadap kualitas sumber daya manusia (SDM) yang akan terjun pada dunia usaha dan dunia industri. Dilihat kondisi saat ini tingkat persaingan di dunia usaha dan dunia industri semakin ketat, sehingga menuntut kebutuhan SDM sebagai tenaga kerja yang mempunyai keterampilan, keahlian, dan kemauan yang kuat. Upaya peningkatan nilai tambah pada SDM yaitu dengan cara meningkatkan keterampilan, dan keahlian generasi muda Indonesia yang akan memasuki dunia kerja. Untuk memenuhi peningkatan nilai tambah SDM tersebut maka dibentuk lembaga pendidikan kejuruan, yang salah satu diantaranya adalah Sekolah Menengah Kejuruan (SMK).

Sistem pendidikan yang diterapkan di SMK saat ini merupakan ujung tombak dari kualitas lulusan SMK yang ada di Indonesia dimata dunia usaha maupun dunia industri. Sistem pendidikan yang dibangun dan diterapkan itu harus disesuaikan dengan tuntutan zaman agar pendidikan dapat menghasilkan outcome atau lulusan yang relevan dan berkualitas sesuai dengan kebutuhan dan persoalan aktual yang dihadapi oleh bangsa.

Pendidikan Sistem Ganda merupakan sistem pendidikan yang menerapkan teknik pendidikan di sekolah dan di dunia industri. Pendidikan Sistem Ganda atau yang lebih dikenal dengan PSG ini diterapkan oleh Pemerintah Indonesia untuk Sekolah Menengah Kejuruan (SMK). Pendidikan Sistem Ganda ini cukup meyakinkan pemerintah, guru dan masyarakat bahwa sekarang SMK sudah mulai dapat diterima di Dunia Usaha dan Dunia Industri (DU/DI).
Praktik Kerja Industri atau biasa lebih dikenal dengan sebutan Prakerin, merupakan suatu mata pelajaran yang memadukan kegiatan belajar di sekolah dengan belajar di tempat kerja sesuai dengan bidang masingmasing, prakerin juga salah satu mata pelajaran yang wajib tempuh untuk siswasiswi SMK. prakerin dilaksanakan oleh siswa-siswa di DU/DI yang telah ditetapkan oleh lembaga sekolah, namun terkadang prakerin juga dilakukan di DU/DI yang telah ditunjuk sendiri oleh siswa yang bersangkutan.

Selain perbaikan sistem pendidikan, upaya lain dalam mengembangkan kualitas SDM yang ada adalah dengan melihat penilaian dunia usaha dan dunia industri terhadap kinerja siswa praktikan selama masa praktik kerja industri (prakerin), dan membantu memberikan saran dalam peningkatan mutu kerja di dunia pendidikan kejuruan.

Tanggapan terhadap kinerja siswa praktikan khususnya pada soft skills dan hard skills masih belum banyak dilakukan oleh pihak sekolah, maka sangat diperlukan permintaan tanggapan dari pihak sekolah kepada dunia usaha dan dunia industri terhadap sistem pendidikan yang diterapkan di sekolah kejuruan. Apakah sistem pendidikan saat ini sudah mampu meningkatkan kualitas kerja siswa yang melaksanakan praktikum, jika belum maka perlu dilakukan evaluasi oleh pihak sekolah bagaimana cara meningkatkan mutu keterampilan dan pengetahuan siswa.

Hal ini diperoleh dengan melakukan observasi yang berupa wawancara pihak sekolah, terutama dengan pihak Kaprodi Desain Pemodelan dan Informasi Bangunan di SMKN 2 Garut. Dengan adanya peneltian ini, maka akan diketahui bagaimana tanggapan dunia usaha dan dunia industri 
terhadap pelaksanaan praktik kerja industri serta hasil kinerja yang ditinjau dari soft skill dan hard skill pada siswa - siswi yang telah melaksanakan prakerin.

\section{METODE}

Penelitian ini merupakan penelitian deskriptif yang diolah secara kuantitatif dan menggunakan pendekatan survei. Tujuan dari penelitian ini yaitu mengetahui tanggapan responden terhadap objek yang telah ditentukan. Penelitian survei merupakan penelitian ilmiah yang menggunakan pendekatan dasar, guna mengetahui berbagai pola perilaku, pola sikap, dan opini responden (Musfiqon, 2012, hlm. 67). Pendekatan deskriptif kuantitatif menurut Arikunto (2010, hlm. 234) tidak dimaksudkan untuk menguji hipotesis tertentu, tetapi hanya menggambarkan apa adanya tentang suatu variabel, gejala atau keadaan.

Partisipan yang dipilih unuk penelitian ini adalah pembimbing siswa dari pihak industri dalam pelaksanaan praktik kerja industri. Populasi pada penelitian ini berjumlah 28 industri. Bidang perusahaan yang menerima siswa SMK Negeri 2 Garut untuk melaksanakan pratik kerja industri diantaranya 16 perusahaan dibidang konsultan dan 12 perusahaan dibidang kontraktor. Berdasarkan data yang diperoleh dari pihak sekolah, tempat praktik industri yang dipilih oleh siswa SMK Negeri 2 Garut sebagian besar di wilayah kabupaten Garut, sisanya di luar wilayah kabupaten Garut, seperti Bandung, Jakarta, Tangerang. Dalam penelitian ini, untuk teknik pengambilan sampel menggunakan teknik sampling jenuh, karena dilihat dari populasinya kurang dari 30 orang. (Sugiyono, 2011, hlm. 68). Sehingga sampel pada penelitian ini yaitu seluruh anggota dari populasi itu sendiri.

Dalam mengumpulkan data, penelitian ini membutuhkan instrumen penelitian. Dalam kisi-kisi instrumen terdapat variabel yang diteliti, indikator sebagai tolak ukur dan nomor butir pertanyaan atau pernyataan yang telah dijabarkan dari indikator. Riduwan dan Akdon (2009, hlm. 16) mengemukakan dengan skala likert, variabel yang akan dibutuhkan dijabarkan menjadi dimensi, dimensi dijabarkan menjadi sub variabel kemudian sub variabel dijabarkan lagi menjadi indikator-indikator yang dapat diukur.

Menurut Sugiyono. (2011, hlm. 352) untuk menguji validitas konten dapat digunakan pendapat dari para ahli (judgement expert), dengan jumlah tenaga ahli yang digunakan minimal tiga orang dan mereka yang sesuai dengan lingkup yang diteliti. Setelah instrumen diperiksa dan layak digunakan, maka kuesioner langsung disebar tanpa harus diuji validitas maupun reliabilitas, karena sampel pada penelitian ini kurang dari 30 orang sehingga tidak dapat melakukan uji coba instrumen.

Analisis statistik deskriptif dalam penelitian ini menghitung harga rata-rata mean (M), skor tertinggi, skor terendah dan standar deviasi atau simpangan baku (SD) serta untuk menghitung setiap butir dalam kuesioner menggunakan persentase, dengan menggunakan rumus menurut Anas (2005, hlm. 40).

$$
P=\frac{f_{o}}{N} X 100 \%
$$

Keterangan:

P : Persentase

Fo : Frekuensi yang sedang dicari

$\mathrm{N}$ : Jumlah total frekuensi

Interpretasi hasil penelitian ini dikategorikan dalam empat kriteria yaitu 
Tanggapan Dunia... (Winda/ hal. 85-99)

sangat baik, baik, kurang baik, dan tidak baik. Norma kategori dan norma pembanding (kriteria pembanding) menggunakan empat jenjang kategori dengan luas interval berjarak 1,5 SD (Azwar, 2012, hal. 148), kategori tersebut terdapat pada Table 1.

Tabel 1. Interval Penilaian

\begin{tabular}{ll}
\hline \multicolumn{1}{c}{ Skala data } & \multicolumn{1}{c}{ Kriteria } \\
\hline $\mathrm{X} \geq \mathrm{M}+1,5 \mathrm{SD}$ & Sangat Baik \\
$\mathrm{M} \leq \mathrm{X}<\mathrm{M}+1,5 \mathrm{SD}$ & Baik \\
$\mathrm{M}-1,5$ (SD) $\leq \mathrm{X}<\mathrm{M}$ & Kurang Baik \\
$\mathrm{X}<(\mathrm{M}-1,5 \mathrm{SD})$ & Tidak Baik \\
\hline Note. $\mathrm{M}=$ Nilai Rata-rata; $\mathrm{SD}=$ Standar Deviasi \\
(simpangan baku)
\end{tabular}

Cara untuk mengetahui deskripsi variabel ini dengan merata-ratakan skor atau dengan menjumlahkan skor dari tiap item pernyataan yang kemudian dirata-ratakan dari nomor item pernyataan per indikatornya. Agar hasilnya lebih mudah untuk dibaca maka dibuat diagram batang digunakan perhitungan persentase. Persentase jawaban kemudian diinterpretasikan dengan kriteria interpretasi skor yang berpedoman pada batasan yang dikembangkan dengan bahasa penafsiran, dapat dilihat pada Tabel 2.

Tabel 2. Kriteria Pedoman Penafsiran Persentase

\begin{tabular}{ll}
\hline \multicolumn{1}{c}{ Persentase } & \multicolumn{1}{c}{ Kriteria } \\
\hline $0 \%-20,99 \%$ & Sangat Rendah \\
$21 \%-40,99 \%$ & Rendah
\end{tabular}

\begin{tabular}{ll}
\hline \multicolumn{1}{c}{ Persentase } & \multicolumn{1}{c}{ Kriteria } \\
\hline $41 \%-60,99 \%$ & Cukup \\
$61 \%-80,99 \%$ & Tinggi \\
$81 \%-100 \%$ & Sangat Tinggi \\
\hline (Sumber: Arikunto, 2010, hlm. 107)
\end{tabular}

\section{HASIL DAN PEMBAHASAN}

Penyebaran dan pengisian kuesioner mengenai tanggapan industri terhadap soft skills dan hard skills siswa SMK dalam pelaksanaan prakerin dilakukan kepada pembimbing siswa prakerin. Aspek soft kills yang diambil peneliti disesuaikan dengan konsep 4C, diantaranya yaitu: (1) Komunikasi (Communication), Kolaboratif (Collaboration), (3) Berpikir Kritis dan Pemecahan Masalah (Critical Thinking and Problem Solving), (4) Kreativitas dan Inovasi (Creativity and Innovation). Keempat indikator ini diukur pencapaiannya menurut responden dari penyebaran dan pengisian kuesioner yang telah dilakukan.

Hasil perhitungan untuk aspek soft skills, dari jumlah skor/bobot jawaban butir pernyataan tiap responden didapatkan nilai maksimum 107 , nilai minimum 73 , nilai rata-rata 90, simpangan baku 5,67. Selanjutnya diperoleh hasil seperti dalam tabel.

Tabel 3. Persentase Aspek Seft Skill SMKN 2 Garut dalam Pelaksanaan Prakerin

\begin{tabular}{llllllllll}
\hline No & \multicolumn{3}{c}{ Tabel Konversi } & & & Kriteria & fo & Persentase (\%) \\
\hline 1 & $\mathrm{M}+1,5 \mathrm{SD} \leq \mathrm{X}$ & 98,5 & $\leq$ & $\mathrm{X}$ & & & Sangat Baik & 7 & 28 \\
2 & $\mathrm{M} \leq \mathrm{X}<\mathrm{M}+1,5 \mathrm{SD}$ & 90,0 & $\leq$ & $\mathrm{X}$ & $<$ & 98,5 & Baik & 11 & 44 \\
3 & $\mathrm{M}-1,5 \mathrm{SD} \leq \mathrm{X}<\mathrm{M}$ & 81,5 & $\leq$ & $\mathrm{X}$ & $\leq$ & 90,0 & Kurang Baik & 5 & 20 \\
4 & $\mathrm{X}<\mathrm{M}-1,5 \mathrm{SD}$ & & & $\mathrm{X}$ & $<$ & 81,5 & Tidak Baik & 2 & 8 \\
\hline
\end{tabular}

Berdasarkan hasil pengolahan data pada tabel dari aspek soft skills ditandai dengan $28 \%$ pada kriteria sangat baik, $44 \%$ pada kriteria baik, 20\% pada kriteria kurang baik, dan $8 \%$ pada kriteria tidak baik. Jika dikelompokkan dan diakumulasikan tanggapan positif pada aspek ini sebesar $72 \%$, sedangkan tangapan negatif pada aspek ini sebesar 28\%. Dilihat dari hasil tersebut dapat disimpulkan gambaran umum 
pada aspek soft skills yaitu termasuk kategori baik dengaan persentase $44 \%$. Selanjutnya secara lebih rinci perolehan persentase gambaran kecenderungan tanggapan dunia industri pada tiap indikator akan dipaparkan pada Tabel 4.

Tabel 4. Persentase kecenderungan tiap indicator pada aspek soft skills

\begin{tabular}{|c|c|c|c|}
\hline Indikator & Kriteria & fo & $\begin{array}{c}\text { Persentase } \\
(\%)\end{array}$ \\
\hline \multirow[t]{4}{*}{$\begin{array}{l}\text { Komunikasi } \\
\text { (Communication) }\end{array}$} & $\begin{array}{l}\text { Sangat } \\
\text { Baik }\end{array}$ & 7 & 28 \\
\hline & Baik & 12 & 48 \\
\hline & $\begin{array}{l}\text { Kurang } \\
\text { Baik }\end{array}$ & 3 & 12 \\
\hline & $\begin{array}{l}\text { Tidak } \\
\text { Baik }\end{array}$ & 3 & 12 \\
\hline \multirow{4}{*}{$\begin{array}{l}\text { Berpikir Kritis dan } \\
\text { Pemecahan } \\
\text { Masalah (Critical } \\
\text { Thinking and } \\
\text { Problem Solving) }\end{array}$} & $\begin{array}{l}\text { Sangat } \\
\text { Baik }\end{array}$ & 4 & 16 \\
\hline & Baik & 9 & 36 \\
\hline & Kurang & 7 & 28 \\
\hline & $\begin{array}{l}\text { Baik } \\
\text { Tidak } \\
\text { Baik } \\
\end{array}$ & 5 & 20 \\
\hline \multirow[t]{4}{*}{$\begin{array}{l}\text { Kolaboratif } \\
\text { (Collaborative) }\end{array}$} & $\begin{array}{l}\text { Sangat } \\
\text { Baik }\end{array}$ & 8 & 32 \\
\hline & Baik & 9 & 36 \\
\hline & $\begin{array}{l}\text { Kurang } \\
\text { Baik }\end{array}$ & 7 & 28 \\
\hline & $\begin{array}{l}\text { Tidak } \\
\text { Baik }\end{array}$ & 1 & 4 \\
\hline \multirow{5}{*}{$\begin{array}{l}\text { Kreativitas dan } \\
\text { Inovasi (Creativity } \\
\text { and Innovation) }\end{array}$} & Sangat & 7 & 28 \\
\hline & Baik & & \\
\hline & Baik & 13 & 52 \\
\hline & $\begin{array}{l}\text { Kurang } \\
\text { Baik }\end{array}$ & 4 & 16 \\
\hline & $\begin{array}{l}\text { Tidak } \\
\text { Baik }\end{array}$ & 1 & 4 \\
\hline
\end{tabular}

Dari pemaparan hasil analisis pada tabel 4 diperoleh hasil persentase kecenderungan tiap pada aspek soft skills, sehingga gambaran tanggapan dunia industri mengenai soft skills siswa SMK Negeri 2 Garut dalam pelaksanaan prakerin berdasarkan tiap indikator yaitu pada indikator komunikasi (communication) disimpulkan sebanyak 19 responden dari 25 responden menanggapi baik atas kemampuan komunikasi yang dimiliki oleh siswa SMKN 2 Garut pada pelaksanaan prakerin. Indikator komunikasi terdiri dari beberapa butir pernyataan. Dari butir ratarata tertinggi dan terendah, menggambarkan bahwa rata-rata butir tertinggi yaitu termasuk kedalam komunikasi informal, artinya komunikasi ini dilakukan dalam percakapan sehari-hari dengan suasana lebih santai. Sedangkan untuk rata-rata terendah termasuk kedalam komunikasi formal. Hambatan yang kerap menjadi masalah komunikasi formal yaitu terkait dengan rendahnya kepercayaan siswa dan minimnya informasi yang dimiliki untuk menyampaikan topik diskusi. Oleh sebab itu, siswa perlu membiasakan diri untuk banyak membaca dan dibantu oleh guru untuk menugaskan siswa agar meringkas isi bacaan dan melaporkan hasil ringkasan. Siswa yang menguasai materi berdasarkan hasil pemikiran dan ringkasan secara pribadi akan lebih percaya diri untuk berbicara dalam konteks formal daripada siswa yang tidak menguasai materi. Beberapa strategi dapat dilakukan untuk meningkatkan keterampilan komunikasi dalam aspek literasi berbahasa siswa di antaranya melalui presentasi di kelas, melakukan simulasi pembaca berita atau wawancara, melakukan diskusi kecil maupun diskusi panel, atau mengimplementasikan model problem based learning.

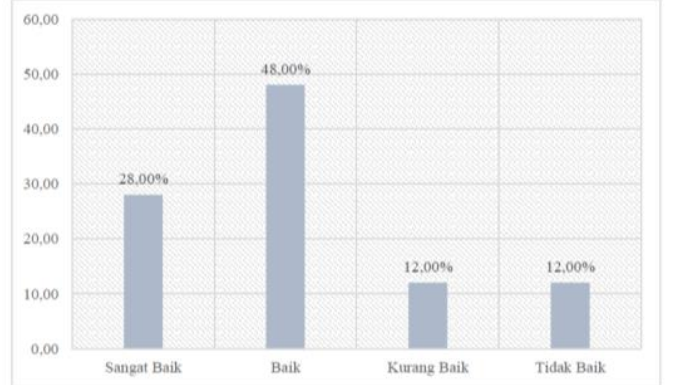

Gambar 1. Diagram Uji Kecenderungan Komunikasi (Communication)

Indikator kedua yaitu kolaboratif (collaborative) disimpulkan sebanyak 17 responden dari 25 responden menanggapi 
baik atas kemampuan kolaboratif yang dimiliki oleh siswa SMKN 2 Garut pada pelaksanaan prakerin. Indikator kolaboratif terdiri dari tiga sub indikator. Dilihat dari persentase rata-rata skor, sub indikator yang terendah dari ketiga sub indikator yaitu mengenai beradaptasi, artinya siswa belum sepenuhnya mampu beradaptasi dilingkungan pekerjaan, seperti memposisikan dirinya sebagai praktikan. Ada beberapa faktor yang menyebabkan siswa beradaptasi belum optimal salah satu nya yaitu faktor pengalaman, karena dengan pengalaman kita bisa beradaptasi dengan baik pada sebuah kondisi atau lingkungkan. Sedangkan siswa pada saat melaksanakan prakerin atau terjun ke lingkungan kerja, mereka belum mempunyai pengalaman sebelumnya di lingkungan tersebut. Maka dari itu siswa mengalami kesulitan sehingga belum optimal dalam beradaptasi.

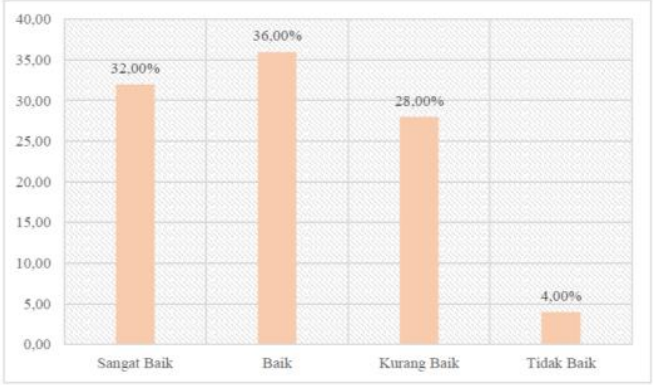

Gambar 2. Diagram Uji Kecenderungan Kolaboratif (Collaborative)

Indikator ketiga yaitu berpikir kritis dan pemecahan masalah (critical thinking and problem solving), terdiri dari dua sub indikator. Dilihat dari persentase rata-rata skor, sub indikator yang terendah yaitu mengenai menyelesaikan masalah, sedangkan yang tertiggi yaitu mengenai memahami dan menganalisis. meskipun begitu pencapaian sub indikator tersebut sebenarnya belum mencapai persentase secara optimal. Ada beberapa faktor yang menyebabkan tidak optimalnya pencapaian kemampuan siswa dalam befikir kritis dan pemecahan masalah yaitu kurang berperan aktif atau kurang rasa ingin tahu sehingga siswa terlihat pasif karena jarang menanyakan hal yang sedang didiskusikan. Adapun strategi untuk mengajarkan kemampuan-kemampuan critical thinking yaitu (1) meningkatkan interaksi di antara para siswa sebagai pembelajar, (2) dengan mengaukan pertanyaan, (3) memberikan waktu yang memadai kepada para siswa untuk memberikan refleksi terhadap pertanyaan yag diajukan atau masalahmasalah yang diberikan. Dari strategi tersebut bahwa pembelajaran yang dapat mengembangkan critical thinking yaitu pembelajaran yang menggunakan pendekatan student center dan menerapkan model pembelajarandimana sintaksnya memberikan kesempatan kepada peserta didik untuk aktif.

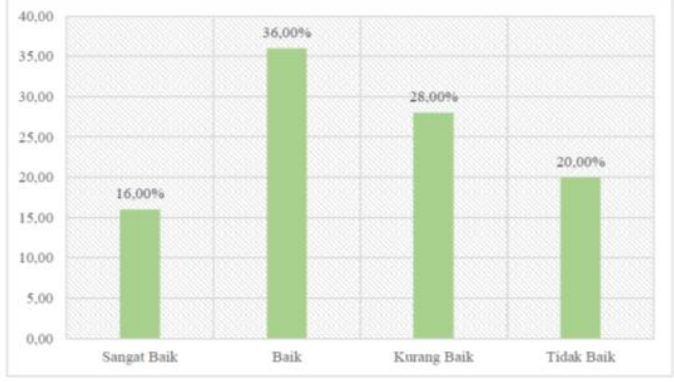

Gambar 3. Diagram Uji Kecenderungan Berfikir Kritis dan Pemecahan Masalah (Critical Thinking and Problem Solving)

Indikator keempat yaitu kreativitas dan inovasi (creativity and innovation) terdiri dari dua sub indikator. Dilihat dari persentase rata-rata skor, sub indikator yang tertinggi pencapaiannya mengenai mampu mengembangkan gagasan-gagasan, termasuk kategori tinggi. Artinya bahwa siswa dalam pelaksanaan prakerin memiliki sikap terbuka atau menerima suatu gagasan baru dan memahaminya, sehingga mampu mengembangkan ide/gagasan kreatif untuk menghasilkan sesuatu yang berguna bagi perusahaan. Proses hasil kreativitas meliputi 
ide orisinil, cara pandang berbeda, memecahkan masalah, mengkombinasikan kembali gagasan-gagasan atau melihat hubungan baru di antara gagasan-gagasan tersebut.

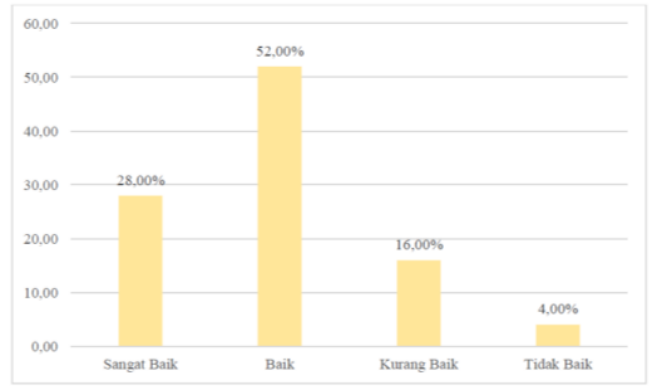

Gambar 4. Diagram Uji Kecenderungan Kreativitas dan Inovasi (Creativity and Innovation)
Berikut ini temuan persentase aspek hardkills siswa SMKN 2 Garut dalam pelaksanaan prakerin dengan kategori pencapaian yang mengacu pada interval penilaian pada tabel 1. Hasil perhitungan untuk aspek hard skills, dari jumlah skor/bobot jawaban butir pernyataan tiap responden didapatkan nilai maksimum 113 , nilai minimum 51 , nilai rata-rata 82 , simpangan baku 10,33. Selanjutnya diperoleh hasil seperti pada Tabel 5.

Tabel 5. Persentase aspek Hard Skills siswa SMKN 2 Garut dalam pelaksanaan Prakerin

\begin{tabular}{llllllllcc}
\hline No & \multicolumn{3}{c}{ Tabel Konversi } & & & Kriteria & fo & Persentase (\%) \\
\hline 1 & $\mathrm{M}+1,5 \mathrm{SD} \leq \mathrm{X}$ & 97,5 & $\mathrm{X}$ & & & Sangat Baik & 3 & 12 \\
2 & $\mathrm{M} \leq \mathrm{X}<\mathrm{M}+1,5 \mathrm{SD}$ & $82,0 \leq$ & $\mathrm{X}$ & $<$ & 97,5 & Baik & 8 & 32 \\
3 & $\mathrm{M}-1,5 \mathrm{SD} \leq \mathrm{X}<\mathrm{M}$ & $66,5 \leq$ & $\mathrm{X}$ & $\leq$ & 82,0 & Kurang Baik & 8 & 32 \\
4 & $\mathrm{X}<\mathrm{M}-1,5 \mathrm{SD}$ & & & $\mathrm{X}$ & $<$ & 66,5 & Tidak Baik & 6 & 24 \\
\hline
\end{tabular}

Berdasarkan hasil pengolahan data pada tabel dari aspek hard skills ditandai dengan $12 \%$ pada kriteria sangat baik, $32 \%$ pada kriteria baik, $32 \%$ pada kriteria kurang baik, dan $24 \%$ pada kriteria tidak baik. Jika dikelompokkan dan dikumulasikan tanggapan positif pada aspek ini sebesar $44 \%$, sedangkan tangapan negatif pada aspek ini sebesar 56\%. Dilihat dari hasil tersebut dapat disimpulkan gambaran umum pada aspek hard skills yaitu termasuk kategori kurang baik dengan persentase $32 \%$. Selanjutnya secara lebih rinci perolehan persentase gambaran kecenderungan tanggapan dunia industri pada tiap indikator akan dipaparkan pada Tabel 6.

Tabel 6. Persentase kecenderungan tiap indicator pada aspek hard skills

\begin{tabular}{llcc}
\hline \multicolumn{1}{c}{ Indikator } & Kriteria & fo & $\begin{array}{c}\text { Persentase } \\
(\boldsymbol{\%})\end{array}$ \\
\hline $\begin{array}{l}\text { Menggambar } \\
\text { Lanjut dengan }\end{array}$ & $\begin{array}{l}\text { Sangat } \\
\text { Baik }\end{array}$ & 5 & 20 \\
\end{tabular}

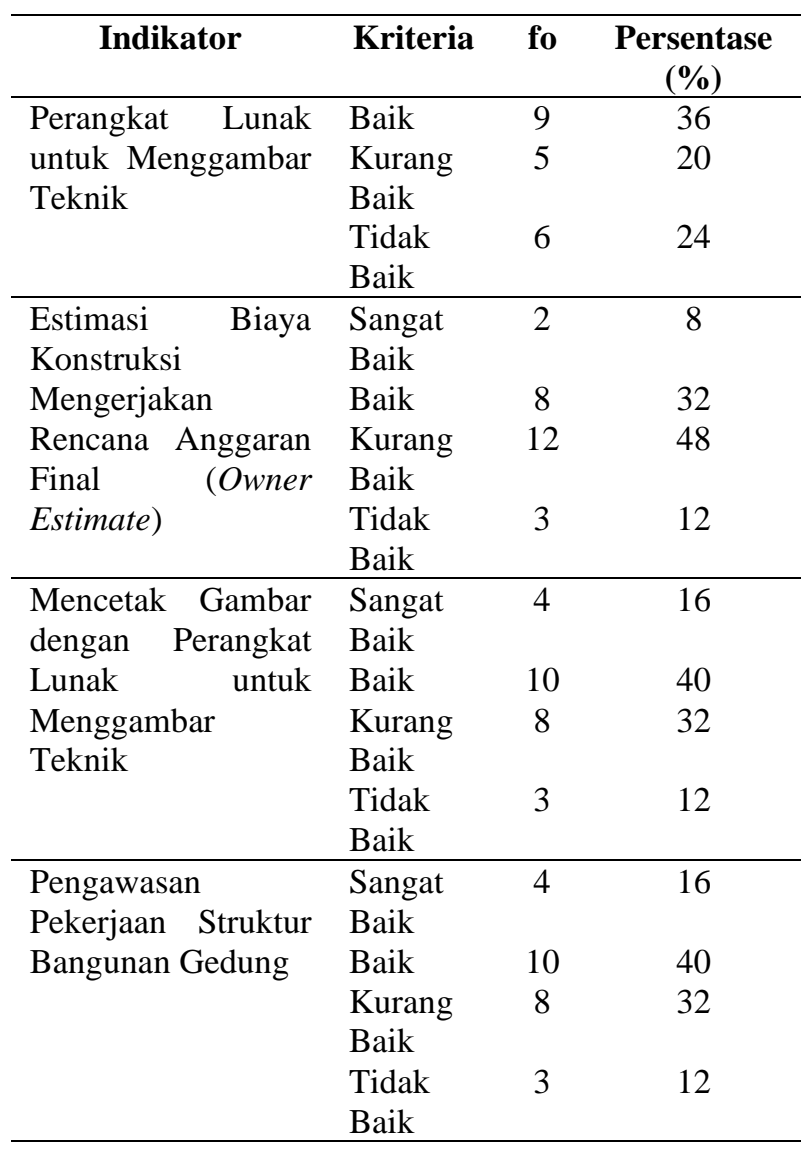


Dari pemaparan hasil analisis pada tabel 6 diperoleh hasil persentase kecenderungan tiap pada aspek hard skills, sehingga gambaran tanggapan dunia industri mengenai hard skills siswa SMK Negeri 2 Garut dalam pelaksanaan prakerin berdasarkan tiap indikator yaitu pada indikator menggambar lanjut dengan perangkat lunak untuk menggambar teknik disimpulkan bahwa tanggapan responden baik atas indikator ini. Indikator ini terdiri dari dua sub indikator. Dilihat dari persentase rata-rata skor, sub indikator yang terendah yaitu mengenai modifikasi wblock dan external reference, artinya bahwa kompetensi siswa dalam hal ini masih belum sepenuhnya dikuasai. Hal tersebut menandakan bahwa kompetensi sebelumnya belum terkuasai. Sesuai Standar Kompetensi Kerja Nasional Indonesia (SKKNI), untuk mencapai kompetensi menggambar lanjut dengan perangkat lunak untuk menggambar teknik ini, siswa harus menguasai terlebih dahulu kompetensi mengelola file dan folder pada sistem operasi dan menggambar dasar dengan perangkat lunak untuk menggambar.

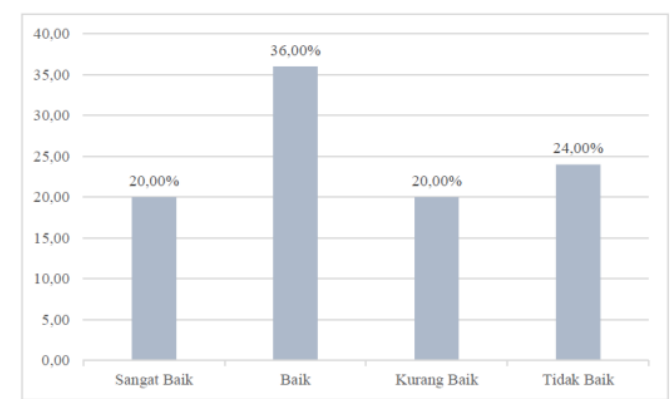

Gambar 5. Diagram Uji Kecenderungan Indikator Menggambar Lanjut dengan Perangkat Lunak untuk Menggambar Teknik

Indikator kedua yaitu mencetak gambar dengan perangkat lunak untuk menggambar teknik disimpulkan bahwa tanggapan responden baik atas indikator ini. Indikator ini terdiri dari dua sub indikator. Dilihat dari persentase rata-rata skor, sub indikator yang terendah yaitu mengenai menentukan skala gambar dan memilih gambar yang akan dicetak, artinya bahwa kompetensi siswa dalam hal ini masih belum sepenuhnya dikuasai. Hal tersebut menandakan bahwa kompetensi sebelumnya belum terkuasai. Sesuai Standar Kompetensi Kerja Nasional Indonesia (SKKNI), untuk mencapai kompetensi mencetak gambar dengan perangkat lunak untuk menggambar teknik ini, siswa harus menguasai terlebih dahulu kompetensi mengatur tata letak gambar pada model space dengan perangkat.

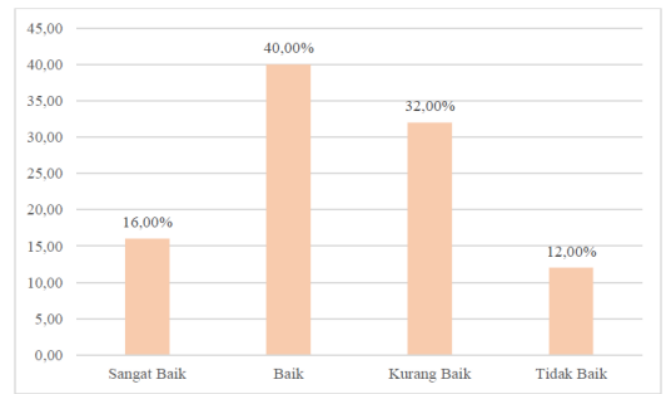

Gambar 6. Diagram Uji Kecenderungan Indikator Mencetak Gambar dengan Perangkat Lunak untuk Menggambar Teknik

Indikator ketiga yaitu estimasi biaya konstruksi mengerjakan rencana anggaran final (owner estimate) disimpulkan bahwa tanggapan responden kurang baik atas indikator ini. Indikator ini terdiri dari dua sub indikator. Dilihat dari persentase ratarata skor, sub indikator yang terendah yaitu mengenai menghitung volume dan membuat analisis harga satuan global, artinya bahwa kompetensi siswa dalam hal ini masih belum sepenuhnya dikuasai. Hal tersebut menandakan bahwa kompetensi sebelumnya belum terkuasai. Sesuai Standar Kompetensi Kerja Nasional Indonesia (SKKNI), untuk mencapai kompetensi estimasi biaya konstruksi mengerjakan rencana anggaran final (owner estimate) ini, siswa harus menguasai terlebih dahulu kompetensi 
menyiapkan rencana anggaran (cost plan) berdasarkan gambar desain tahap skematik dan pengembangan desain (design development).

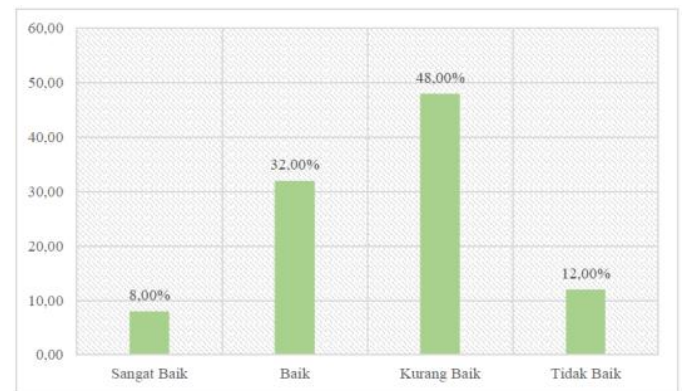

Gambar 7. Diagram Uji Kecenderungan Indikator Estimasi Biaya Konstruksi Mengerjakan Rencana Anggaran Final (Owner Estimate)

Indikator keempat yaitu pengawasan pekerjaan struktur bangunan gedung disimpulkan bahwa tanggapan responden baik atas indikator ini. Indikator ini terdiri dari dua sub indikator. Dilihat dari persentase rata-rata skor, sub indikator yang terendah yaitu mengenai mengawasi pekerjaan struktur bawah bangunan gedung, artinya bahwa kompetensi siswa dalam hal ini masih belum sepenuhnya dikuasai. Hal tersebut menandakan bahwa kompetensi sebelumnya belum terkuasai. Sesuai Standar Kompetensi Kerja Nasional Indonesia (SKKNI), untuk mencapai kompetensi pengawasan pekerjaan struktur bangunan gedung ini, siswa harus menguasai terlebih dahulu kompetensi melakukan komunikasi di tempat kerja.

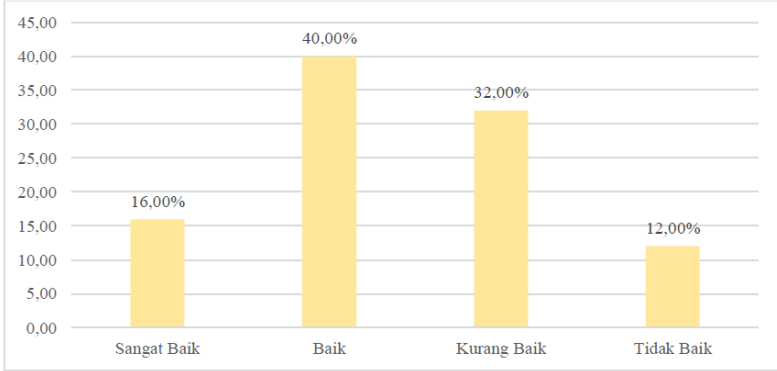

Gambar 8. Diagram Batang Indikator Pengawasan Pekerjaan Struktur Bangunan Gedung
Tanggapan Dunia Industri terhadap Soft Skills dalam Pelaksanaan Praktik Kerja Industri

Berdasarkan dari hasil analisa kuesioner yang telah dilakukan, dilihat dari persentase kecenderungan tanggapan dunia industri memperlihatkan tanggapan responden baik atas kompetensi siswa dalam Soft skil yang dimiliki oleh siswa SMKN 2 Garut pada pelaksanaan prakerin. Baik itu pada indikator komunikasi, kolaboratif, berpikir kritis dan pemecahan masalah serta kreatifivitas dan inofatif.

Indikator komunikasi terdiri dari dua sub indikator. Dilihat dari persentase ratarata skor, sub indikator komunikasi lisan termasuk ke dalam kategori tinggi. Sub indikator ini digambarkan melalui tiga butir pernyataan, diantara ketiga butir tersebut rata-rata tertinggi terdapat pada butir mengenai saat berkonsultasi dengan pembimbing lapangan siswa menggunakan kalimat yang mudah dipahami. Hal ini menandakan bahwa mayoritas responden yaitu pembimbing/pendamping siswa saat prakerin merasa bahwa siswa mampu berkomunikasi dengan baik sehingga apa yang disampaikan oleh siswa tersebut penyampaiannya dengan jelas.

Kemudian rata-rata butir terendah terdapat pada butir mengenai saat siswa berbicara didepan banyak orang. Hal ini menandakan bahwa mayoritas responden merasa bahwa siswa saat berbicara di khalayak umum mudah gugup, seperti halnya untuk mengutarakan gagasan baik dalam diskusi atau pada saat persentasi. Hal ini menyebabkan keterampilan atau kemampuan bicara siswa kurang efektif.

Dari butir rata-rata tertinggi dan terendah, menggambarkan bahwa rata-rata butir tertinggi yaitu termasuk kedalam komunikasi informal, artinya komunikasi ini 
dilakukan dalam percakapan sehari-hari dengan suasana lebih santai. Sedangkan untuk rata-rata terendah termasuk kedalam komunikasi formal. Hambatan yang kerap menjadi masalah komunikasi formal yaitu terkait dengan rendahnya kepercayaan siswa dan minimnya informasi yang dimiliki untuk menyampaikan topik diskusi. Oleh sebab itu, siswa perlu membiasakan diri untuk banyak membaca dan dibantu oleh guru untuk menugaskan siswa agar meringkas isi bacaan dan melaporkan hasil ringkasan. Siswa yang menguasai materi berdasarkan hasil pemikiran dan ringkasan secara pribadi akan lebih percaya diri untuk berbicara dalam konteks formal daripada siswa yang tidak menguasai materi. Beberapa strategi dapat dilakukan untuk meningkatkan keterampilan komunikasi dalam aspek literasi berbahasa siswa di antaranya melalui presentasi di kelas, melakukan simulasi pembaca berita atau wawancara, melakukan diskusi kecil maupun diskusi panel, atau mengimplementasikan model problem based learning.

Rata-rata kedua sub indikator merupakan gambaran pencapaian tanggapan responden mengenai kemampuan atau keterampilan komunikasi siswa SMK Negeri 2 Garut dalam pelaksanaan prakerin. Pencapaian tanggapan dunia industri dalam kategori tinggi. Sehingga dapat disimpulkan bahwa keterampilan komunikasi siswa SMKN 2 Garut dari sudut pandang dunia industri sudah baik.

Indikator kolaboratif terdiri dari tiga sub indikator. Dilihat dari persentase ratarata skor, sub indikator yang terendah dari ketiga sub indikator yaitu mengenai beradaptasi, namun sub indikator ini termasuk kategori tinggi, artinya siswa belum sepenuhnya mampu beradaptasi dilingkungan pekerjaan, seperti tidak canggung untuk menyapa dan berkenalan dengan yang lainnya, memperhatikan aturan yang ada dilingkungan, serta memposisikan dirinya sebagai praktikan.

Ada beberapa faktor yang menyebabkan siswa beradaptasi belum optimal salah satu nya yaitu faktor usia dan pengalaman, karena usia adalah sebuah ukuran dari seseoramg yang bisa melakukan adaptasi dengan baik. Siswa pada saat melaksanakan prakerin itu belum cukup matang, dapat disebut masih usia remaja. Dari kematangan usia contohnya, tentu kita memiliki cara berpikir yang matang, apalagi di dalam suatu lingkungan baru juga menjadi ukuran dalam penentu tingkat kepercayaan seseorang. Dan dilihat dari faktor pengalaman juga, karena dengan pengalaman kita bisa beradaptasi dengan baik pada sebuah kondisi atau lingkungkan. Sedangkan siswa pada saat melaksanakan prakerin atau terjun ke lingkungan kerja, mereka belum mempunyai pengalaman sebelumnya di lingkungan tersebut. Maka dari itu siswa mengalami kesulitan sehingga belum optimal dalam beradaptasi.

Rata-rata sub indikator yang tertinggi pencapaiannya yaitu mengenai tanggung jawab, termasuk kategori tinggi, artinya bahwa siswa memiliki rasa tangggung jawab yang tinggi. Namun dilihat dari persentase siswa belum optimal pada sub indikator tanggung jawab. Kondisi-kondisi terjadinya kolaboratif, setiap individu anggota kelompok memiliki tanggung jawab terhadap kelompoknya, setiap anggota harus setia pada tugas kelompok, setiap anggota tergantung satu sama lainnya.

Ketiga sub indikator ini memberikan gambaran pencapaian tanggapan responden mengenai kemampuan atau keterampilan dalam kolaboratif (collaborative) siswa SMK Negeri 2 Garut dalam pelaksanaan 
prakerin. Pencapaian tanggapan dunia industri dalam kategori Tinggi. Sehingga dapat disimpulkan bahwa keterampilan kolaboratif siswa SMKN 2 Garut dari sudut pandang dunia industri sudah baik.

Indikator berpikir kritis dan pemecahan masalah terdiri dari dua sub indikator. Dilihat dari persentase rata-rata skor, sub indikator yang terendah yaitu mengenai menyelesaikan masalah, sedangkan yang tertiggi yaitu mengenai memahami dan menganalisis. Kedua sub indikator tersebut dalam pencapaian persentase termasuk kategori tinggi, meskipun begitu pencapaian sub indikator tersebut sebenarnya belum mencapai persentase secara optimal. Ada beberapa faktor yang menyebabkan tidak optimalnya pencapaian kemampuan siswa dalam befikir kritis dan pemecahan masalah yaitu kurang berperan aktif atau kurang rasa ingin tahu sehingga siswa terlihat pasif karena jarang menanyakan hal yang sedang didiskusikan. Adapun strategi untuk mengajarkan kemampuan-kemampuan critical thinking yaitu (1) meningkatkan interaksi di antara para siswa sebagai pembelajar, (2) dengan mengaukan pertanyaan, (3) memberikan waktu yang memadai kepada para siswa untuk memberikan refleksi terhadap pertanyaan yag diajukan atau masalahmasalah yang diberikan. Dari strategi tersebut bahwa pembelajaran yang dapat mengembangkan critical thinking yaitu pembelajaran yang menggunakan pendekatan student center dan menerapkan model pembelajarandimana sintaksnya memberikan kesempatan kepada peserta didik untuk aktif.

Berpikir menekankan kepada proses mencari dan menemukan pengetahuan melalui interaksi antara individu dengan lingkungan. Hal tersebut mengandung pengertian bahwa pembelajaran berpikir tidak hanya menekankan kepada akumulasi pengetahuan materi, akan tetapi yang diutamakan adalah kemampuan siswa untuk memperoleh pengetahuannya sendiri. Seseorang yang memiliki critical thinking skill cenderung lebih cepat mengidentifikasi informasi yang relevan, memisahkan informasi yang tidak relevan serta memanfaatkan informasi tersebut untuk mencari solusi masalah atau mengambil keputusan, dan jika perlu mencari informasi pendukung yang relevan.

Kedua sub indikator ini memberikan gambaran pencapaian tanggapan responden mengenai kemampuan atau keterampilan berpikir kritis dan pemecahan masalah siswa SMK Negeri 2 Garut dalam pelaksanaan prakerin. Pencapaian tanggapan dunia industri termasuk dalam kategori Tinggi, sehingga dapat disimpulkan bahwa keterampilan berpikir kritis dan pemecahan masalah siswa SMKN 2 Garut dari sudut pandang dunia industri sudah baik.

Indikator kreatifitas dan inovatif terdiri dari dua sub indikator. Dilihat dari persentase rata-rata skor, sub indikator yang tertinggi pencapaiannya mengenai mampu mengembangkan gagasan-gagasan, artinya bahwa siswa dalam pelaksanaan prakerin memiliki sikap terbuka atau menerima suatu gagasan baru dan memahaminya, sehingga mampu mengembangkan ide/gagasan kreatif untuk menghasilkan sesuatu yang berguna bagi perusahaan. Proses hasil kreativitas meliputi ide orisinil, cara pandang berbeda, memecahkan masalah, mengkombinasikan kembali gagasangagasan atau melihat hubungan baru di antara gagasan-gagasan tersebut.

Kedua sub indikator ini memberikan gambaran pencapaian tanggapan responden mengenai kemampuan atau keterampilan 
kreatifitas dan inovatif (creativity and inovation) siswa SMK Negeri 2 Garut dalam pelaksanaan prakerin. Pencapaian tanggapan dunia industri dalam kategori tinggi. Sehingga dapat disimpulkan bahwa keterampilan kreatifitas dan inovatif (creativity and inovation) siswa SMKN 2 Garut dari sudut pandang dunia industri sudah baik.

\section{Tanggapan Dunia Industri terhadap Hard Skills dalam Pelaksanaan Praktik Kerja Industri}

Berdasarkan dari hasil analisa kuesioner yang telah dilakukan, dilihat dari persentase kecenderungan tanggapan dunia industri memperlihatkan tanggapan responden baik atas kompetensi siswa dalam Hard skil yang dimiliki oleh siswa SMKN 2 Garut pada pelaksanaan prakerin. Baik itu pada indikator menggambar lanjut dengan perangkat lunak, mencetak gambar dengan perangkat lunak, estimasi biaya konstruksi dan pengawasan pekerjaan struktur bangunan gedung.

Indikator menggambar lanjut dengan perangkat lunak untuk menggambar teknik terdiri dari dua sub indikator. Dilihat dari persentase rata-rata skor, sub indikator yang terendah yaitu mengenai modifikasi wblock dan external reference namun sub indikator ini termasuk kategori tinggi. Rata-rata sub indikator yang tertinggi pencapaiannya yaitu mengenai mengelompokkan objek dengan aplikasi fitur format termasuk kategori tinggi, artinya bahwa kompetensi siswa dalam hal ini masih belum sepenuhnya dikuasai. Hal tersebut menandakan bahwa kompetensi sebelumnya belum terkuasai. Sesuai Standar Kompetensi Kerja Nasional Indonesia (SKKNI), untuk mencapai kompetensi menggambar lanjut dengan perangkat lunak untuk menggambar teknik ini, siswa harus menguasai terlebih dahulu kompetensi mengelola file dan folder pada sistem operasi dan menggambar dasar dengan perangkat lunak untuk menggambar. Keempat sub indikator ini memberikan gambaran pencapaian tanggapan responden mengenai kompetensi siswa SMK Negeri 2 Garut dalam menggambar lanjut dengan perangkat lunak untuk menggambar teknik pada pelaksanaan prakerin. Pencapaian tanggapan dunia industri dalam kategori tinggi. Sehingga dapat disimpulkan bahwa kompetesensi siswa SMKN 2 Garut dari sudut pandang dunia industri sudah baik.

Indikator mencetak gambar dengan perangkat lunak untuk menggambar teknik terdiri dari dua sub indikator. Dilihat dari persentase rata-rata skor, sub indikator yang terendah yaitu mengenai menentukan skala gambar dan memilih gambar yang akan dicetak, namun sub indikator ini termasuk kategori tinggi. Rata-rata sub indikator yang tertinggi pencapaiannya yaitu mengenai mengatur ketebalan garis termasuk kategori tinggi, artinya bahwa kompetensi siswa dalam hal ini masih belum sepenuhnya dikuasai. Hal tersebut menandakan bahwa kompetensi sebelumnya belum terkuasai. Sesuai Standar Kompetensi Kerja Nasional Indonesia (SKKNI), untuk mencapai kompetensi mencetak gambar dengan perangkat lunak untuk menggambar teknik ini, siswa harus menguasai terlebih dahulu kompetensi mengatur tata letak gambar pada model space dengan perangkat.

Ketiga sub indikator ini memberikan gambaran pencapaian tanggapan responden mengenai kompetensi siswa SMK Negeri 2 Garut dalam mencetak gambar dengan perangkat lunak untuk menggambar teknik pada pelaksanaan prakerin. Pencapaian tanggapan dunia industri dalam kategori tinggi. Sehingga dapat disimpulkan bahwa 
kompetesensi siswa SMKN 2 Garut dari sudut pandang dunia industri sudah baik.

Indikator estimasi biaya konstruksi mengerjakan rencana anggaran final (owner estimate) terdiri dari dua sub indikator. Dilihat dari persentase rata-rata skor, sub indikator yang terendah yaitu mengenai menghitung volume dan membuat analisis harga satuan global, sub indikator ini termasuk kategori cukup tinggi. Rata-rata sub indikator yang tertinggi pencapaiannya yaitu mengenai melakukan pemeriksaan biaya (cost check), artinya bahwa kompetensi siswa dalam hal ini masih belum sepenuhnya dikuasai. Hal tersebut menandakan bahwa kompetensi sebelumnya belum terkuasai. Sesuai Standar Kompetensi Kerja Nasional Indonesia (SKKNI), untuk mencapai kompetensi estimasi biaya konstruksi mengerjakan rencana anggaran final (owner estimate) ini, siswa harus menguasai terlebih dahulu kompetensi menyiapkan rencana anggaran (cost plan) berdasarkan gambar desain tahap skematik dan pengembangan desain (design development).

Ketiga sub indikator ini memberikan gambaran pencapaian tanggapan responden mengenai kompetensi siswa SMK Negeri 2 Garut dalam estimasi biaya konstruksi mengerjakan rencana anggaran final (owner estimate) pada pelaksanaan prakerin. pencapaian tanggapan dunia industri dalam kategori tinggi. Sehingga dapat disimpulkan bahwa kompetensi siswa SMKN 2 Garut dari sudut pandang dunia industri sudah cukup baik.

Indikator pengawasan pekerjaan struktur bangunan gedung terdiri dari dua sub indikator. Dilihat dari persentase ratarata skor, sub indikator yang terendah yaitu mengenai mengawasi pekerjaan struktur bawah bangunan gedung, namun begitu sub indikator ini termasuk kategori tinggi. Ratarata sub indikator yang tertinggi pencapaiannya mengenai melakukan pekerjaan persiapan pengawasan lapangan, artinya bahwa kompetensi siswa dalam hal ini masih belum sepenuhnya dikuasai. Hal tersebut menandakan bahwa kompetensi sebelumnya belum terkuasai. Sesuai Standar Kompetensi Kerja Nasional Indonesia (SKKNI), untuk mencapai kompetensi pengawasan pekerjaan struktur bangunan gedung ini, siswa harus menguasai terlebih dahulu kompetensi melakukan komunikasi di tempat kerja.

Ketiga sub indikator ini memberikan gambaran pencapaian tanggapan responden mengenai kompetensi siswa SMK Negeri 2 Garut dalam pengawasan pekerjaan struktur bangunan gedung pada pelaksanaan prakerin. pencapaian tanggapan dunia industri dalam kategori tinggi. Sehingga dapat disimpulkan bahwa kompetesensi siswa SMKN 2 Garut dari sudut pandang dunia industri sudah baik.

\section{SIMPULAN}

Berdasarkan hasil penelitian dan hasil analisis data yang telah dilakukan, maka dapat disimpulkan bahwa gambaran umum mengenai tanggapan dunia industri terhadap soft skills siswa SMKN 2 Garut dalam pelaksanaan prakerin secara keseluruhan termasuk dalam kategori baik, sedangkan terhadap hardkills siswa SMKN 2 Garut dalam pelaksanaan prakerin secara keseluruhan termasuk dalam kategori kurang baik. Dari tanggapan dunia industri terhadap kedua aspek tersebut mampu mempengaruhi dalam peningkatan kualitas sumber daya manusia, bahwa aspek soft skills dan hard skills sama-sama dibutuhkan, karena dalam dunia industri hard skills 
Tanggapan Dunia... (Winda/ hal. 85-99)

mungkin bisa dipelajari dan diukur secara keilmuan, namun aspek terpenting adalah penunjangnya yaitu soft skills sendiri, karena sof tskills muncul dari diri itu sendiri bagaimana cara siswa sendiri berkomunikasi dan berprilaku dalam dunia industri, maka aspek sof tskill lah yg lebih cenderung dibutuhkan di dunia industri sekarang.

Diharapkan pihak sekolah dapat lebih memaksimalkan upaya peningkatan dalam aspek soft skills maupun hard skills siswa yaitu pada kompetensi-kompetensi sesuai standar yang telah ditetapkan. Apabila upaya ini dilakukan diharapkan pada masa yang akan datang dalam pelaksanaan parkerin berjalan dengan baik sesuai kurikulum dan tuntutan atau kebutuhan perusahaan. Sehingga kualitas kemampuan siswa SMK Negeri 2 Garut dari sudut pandang dunia industri semakin baik dan semakin banyaknya lulusan SMK Negeri 2 Garut yang terserap di dunia industri.

\section{DAFTAR RUJUKAN}

Andayani, E. (2016). Analisis Praktik Kerja Industri Terhadap Penguasaan Skill Siswa Dalam Menghadapi Dunia Kerja Di SMKN Bululawang Malang. Jurnal Insprirasi Pendidikan, 6, (1), 744-754.

Anas, S. (2005). Pengantar Statistik Pendidikan. Jakarta: PT Raja Grafindo Persada.

Arikunto, S. (2010). Prosedur Penelitian Suatu Pendekatan Praktik. Jakarta: Rineka Cipta.

Azwar, S. (2012). Penyusunan Skala Psikologi. Yogyakarta: Pustaka Pelajar
Direktorat Pembinaan Sekolah Menengah Kejuruan. (2017). Pedoman Praktik Kerja Lapangan (PKL). Jakarta: Kemendikbud.

Menteri Tenaga Kerja dan Transmigrasi RI. (2011). Keputusan Menteri Tenaga Kerja dan Transmigrasi Nomor Kep. 06/Men/Tahun 2011 tentang Penetapan Standar Kompetensi Kerja Nasional Indonesia Sektor Konstruksi Untuk Jabatan Kerja Quantity Surveyor Menjadi Standar Kompetensi Kerja Nasional Indonesia. Jakarta: Kemenakertrans.

Menteri Tenaga Kerja dan Transmigrasi RI. (2013). Keputusan Menteri Tenaga Kerja dan Transmigrasi Nomor 340 Tahun 2013 tentang Penetapan Standar Kompetensi Kerja Nasional Indonesia Kategori Konstruksi Golongan Pokok Konstruksi Gedung Golongan Konstruksi Gedung Sub Golongan Konstruksi Gedung Jabatan Kerja Pengawas Pekerjaan Struktur Bangunan Gedung. Jakarta: Kemenakertrans.

Muqowin. (2012). Pengembangan Soft Skills Guru. Yogyakarta: Pedagogi.

Musfiqon. (2012). Panduan Lengkap Metodelogi Penelitian Pendidikan. Jakarta: PT Prestasi Pustaka Karya.

Purwaningsih, I.J.S., Witurachmi, S., \& Zoraifi, R. (2017). Soft Skills Pada Pelaksanaan Magang Dunia Usaha/Dunia Industri. Jurnal: Tata Arta, 3, (2), 11-20. 
Tanggapan Dunia... (Winda/ hal. 85-99)

Riduwan dan Akdon. (2009). Rumus dan Data dalam Aplikasi Statistika. Bandung: Alfabeta.

Sailah, I. (2008). Pengembangan Soft Skills di PerguruanTinggi. Jakarta: Direktorat Jendral Perguruan Tinggi.

Standar Kompetensi Nasional Bidang Teknik Gambar Bangunan (2003). Unit-Unit Kompetensi Bidang Gambar Bangunan. Jakarta: Kemenakertrans.

Sugiyono. (2011). Statistika untuk Penelitian. Bandung: Alfabeta. 